\title{
Gambaran kadar triasilgliserol darah pada pekerja kantor
}

\author{
${ }^{1}$ Yeremias E. Setyawan \\ ${ }^{2}$ Stefana H. M. Kaligis \\ ${ }^{2}$ Murniati Tiho
}

\author{
${ }^{1}$ Kandidat Skripsi Fakultas Kedokteran Universitas Sam Ratulangi Manado \\ ${ }^{2}$ Bagian Biokimia Fakultas Kedokteran Universitas Sam Ratulangi Manado \\ Email: yes_edwin@yahoo.com
}

\begin{abstract}
Triacylglycerol, a type of lipid found in the blood of the body, is the result of the metabolism of food containing lipid and cholesterol. One of the factors that can increase the blood level of triacylglycerol is less of physical inactivity. Physical activity of office workers is considered as low activity. This study was aimed to describe the blood triacylglycerol levels of office workers. This was a descriptive study with a cross sectional design and total sampling method. The reults showed that there were 52 respondents; 48 respondents $(92.31 \%)$ had normal blood triacylglycerol level and 4 respondents $(7.69 \%)$ had blood triacylglycerol level above the normal value. The average value of blood triacylglycerol levels was $95.44 \mathrm{mg} / \mathrm{dL}$, median $85.5 \mathrm{mg} / \mathrm{dL}$, mode $77 \mathrm{mg} / \mathrm{dL}$, minimal value $39 \mathrm{mg} / \mathrm{dL}$, maximal value $254 \mathrm{mg} / \mathrm{dL}$, and standard of deviation $46.52 \mathrm{mg} / \mathrm{dL}$. Conclusion: The majority of office workers had normal blood triacylglycerol.
\end{abstract}

Keywords: triacylglycerol, office worker, physical inactivity

\begin{abstract}
Abstrak: Triasilgliserol merupakan jenis lemak yang dapat ditemukan di dalam darah dan merupakan hasil uraian tubuh dari makanan yang mengandung lemak dan kolesterol yang dikonsumsi. Salah satu faktor yang dapat meningkatkan kadar triasilgliserol dalam darah yaitu kurangnya aktivitas fisik. Aktivitas fisik pada pekerja kantor tergolong aktivitas fisik yang rendah. Penelitian ini bertujuan untuk mengetahui gambaran kadar triasilgliserol darah pada pekerja kantor. Jenis penelitian ialah deskriptif dengan desain potong lintang dan pengambilan sampel secara total sampling. Hasil penelitian mendapatkan 52 responden. Terdapat 48 responden $(92,31 \%)$ dengan kadar triasilgliserol darah dalam batas normal dan 4 responden $(7,69 \%)$ dengan kadar triasilgliserol darah di atas batas normal. Nilai rerata kadar triasilgliserol darah 95,44 mg/dL, median $85,5 \mathrm{mg} / \mathrm{dL}$, modus $77 \mathrm{mg} / \mathrm{dL}$, nilai minimal 39 $\mathrm{mg} / \mathrm{dL}$, nilai maksimal $254 \mathrm{mg} / \mathrm{dL}$, dan standar deviasi 46,52 mg/dL. Simpulan: Sebagian besar pekerja kantor memiliki kadar triasilgliserol darah normal.
\end{abstract}

Kata kunci: triasilgliserol, pekerja kantor, aktivitas fisik rendah

Penyakit tidak menular (PTM) menjadi penyebab utama kematian secara global. Data World Health Organization (WHO) menunjukkan bahwa dari 57 juta kematian yang terjadi di dunia pada tahun 2008, sebanyak 36 juta jiwa atau hampir dua pertiganya disebabkan oleh PTM. ${ }^{1}$ Penyakit kardiovaskular (penyakit jantung koroner, stroke) merupakan salah satu dari empat jenis PTM utama menurut WHO. ${ }^{2}$ Di
Indonesia terjadi peningkatan prevalensi penyakit kardiovaskular. Berdasarkan data Riset kesehatan dasar (Riskesdas) tahun 2007, prevalensi hipertensi sebesar 7,2\% sedangkan pada Riskesdas 2013 meningkat menjadi sebesar 9,4\%. ${ }^{2,3}$ Penyebab utamanya ialah kebiasaan merokok, minum alkohol, pola makan yang tidak teratur, aktivitas fisik yang kurang, dan juga peningkatan kadar TAG dalam darah. ${ }^{4-6}$ 
Kemajuan teknologi saat ini merupakan penyebab dari rendahnya aktivitas fisik yang dilakukan. Kini mesin yang menggantikan sebagian besar kerja fisik dan juga adanya komputer yang mendorong orang duduk untuk waktu yang lama. Hal ini terjadi pada pekerja kantor sehingga mendorong terjadinya peningkatan risiko penyakit degeneratif. Data dari riskesdas 2013 menunjukkan bahwa penduduk Indonesia yang memiliki aktivitas fisik tergolong kurang aktif sebesar 26,1\% dan Sulawesi Utara termasuk provinsi yang penduduknya tergolong kurang aktif yaitu $31,7 \%{ }^{2}$

Peningkatan triasilgliserol (TAG) merupakan salah satu penyebab PJK, disamping itu dapat juga disebabkan oleh faktor usia dan jenis kelamin. ${ }^{7,8}$ Berdasarkan penelitian Nacher dkk risiko penyakit jantung koroner mulai meningkat pada usia 18-39 tahun. $^{9}$ Menurut Tanne et al. yang melakukan studi kohort berskala besar pada 11.177 pasien laki-laki dan perempuan yang menderita penyakit jantung koroner (PJK) setelah diobservasi 6-8 tahun, terdapat 487 pasien yang mengalami stroke iskemik. Pada pasienpasien tersebut kadar rerata serum triasilgliserol lebih tinggi dari yang tidak mengalami stroke iskemik. Studi tersebut menyimpulkan bahwa serum triasilgliserol yang lebih tinggi merupakan faktor risiko untuk stroke iskemik. ${ }^{10}$

Mengacu pada data observasi yang pernah dilakukan oleh LeMura dan Duvillard, ${ }^{11}$ aktivitas fisik berpengaruh terhadap perubahan kadar HDL dan triasilgliserol terutama pada individu yang aktif. Kadar triasilgliserol pada atlit hampir selalu lebih rendah dibandingkan dengan orang yang memiliki aktivitas fisik rendah.

Aktivitas teratur akan meningkatkan aktivitas enzim lipoprotein lipase dan menurunkan aktivitas enzim hepatic lipase. Lipoprotein lipase akan menghidrolisis triasilgliserol yang ada dalam VLDL sehingga meningkatkan konversi VLDL menjadi IDL. Sebagian IDL akan dikonversi menjadi LDL oleh hepatic lipase dan sisanya akan diambil oleh hati dan jaringan perifer dengan perantara reseptor LDL. Mekanisme ini yang menyebabkan terjadinya penurunan kolesterol, LDL dan peningkatan HDL pada peningkatan aktivitas fisik. ${ }^{12}$

Aktivitas fisik pada pekerja kantor tergolong kurang aktif. Aktivitas yang dilakukan lebih banyak duduk sambil bekerja di depan komputer, menulis, serta membaca yang akan mengakibatkan penumpukan lemak dalam tubuh.

Berdasarkan uraian di atas, penulis tertarik untuk meneliti mengenai gambaran kadar TAG darah pada pekerja kantor.

\section{METODE PENELITIAN}

Jenis penelitian ini ialah deskriptif yang dilaksanakan di PT. Bank SULUTGO Manado dan pemeriksaan sampel darah dilakukan di Laboratorium. Penelitian dilaksanakan pada bulan AgustusDesember 2016. Populasi ialah pekerja Tata Usaha Perkantoran. Pengambilan sampel dengan metode total sampling. Terdapat 52 responden yang memenuhi kriteria inklusi yaitu pegawai aktif di Kantor Bank SULUT dengan masa kerja $\geq$ 1 tahun dan lama kerja $\geq 8$ jam dan bersedia menjadi responden.

Variabel penelitian ini yaitu kadar triasilgliserol dalam darah. Pengambilan responden dilakukan dengan membagikan kuesioner, responden menandatangani informed consent dan kemudian diambil darahnya di fossa cubiti

\section{HASIL PENELITIAN}

Responden penelitian sebanyak 52 orang. Dilihat dari karakteristik jenis kelamin, perempuan merupakan responden terbanyak yaitu sebanyak 27 responden $(51,92 \%)$ (Tabel 1).

Tabel 1. Sebaran responden menurut jenis kelamin

\begin{tabular}{clc}
\hline Jenis Kelamin & $(\mathrm{n})$ & $(\%)$ \\
\hline Laki-laki & 25 & 48,08 \\
Perempuan & 27 & 51,92 \\
Total & 52 & 100 \\
\hline
\end{tabular}


Dari hasil pemeriksaan laboratorium didapatkan sebagian besar responden mempunyai kadar TAG yang normal yaitu 48 responden $(92,31 \%)$ (Tabel 2). Uji analisis univariat kadar TAG dalam darah mendapatkan kadar rerata TAG yaitu 95,44 $\mathrm{mg} / \mathrm{dL}$, median $85,5 \mathrm{mg} / \mathrm{dL}$, modus 77 $\mathrm{mg} / \mathrm{dL}$, nilai minimal $39 \mathrm{mg} / \mathrm{dL}$, nilai maksimal $254 \mathrm{mg} / \mathrm{dL}$, dan standar deviasi $46,52 \mathrm{mg} / \mathrm{dL}$.

Berdasarkan jenis kelamin, dari 25 responden laki-laki, ditemukan sebanyak 4 responden memiliki kadar TAG yang tinggi (16\%) (Tabel 3) sedangkan pada responden perempuan ditemukan sebanyak 27 responden atau seluruh responden memiliki kadar TAG normal (100\%) (Tabel 4).

Tabel 2. Sebaran responden menurut kadar TAG dalam darah

\begin{tabular}{cccc}
\hline $\begin{array}{c}\text { Kadar TAG } \\
(\mathbf{m g} / \mathbf{d L})\end{array}$ & $(\mathbf{\%})$ & $\begin{array}{c}\text { Rata-rata TAG } \\
(\mathbf{m g} / \mathbf{d L})\end{array}$ \\
\hline $\begin{array}{c}\text { Rendah } \\
(<30)\end{array}$ & 0 & 0 & 0 \\
$\begin{array}{c}\text { Normal } \\
(30-190)\end{array}$ & 48 & 92,31 & 85,69 \\
$\begin{array}{c}\text { Tinggi } \\
(>190)\end{array}$ & 4 & 7,69 & 212,5 \\
Total & 52 & 100 & 95,44 \\
\hline
\end{tabular}

Berdasarkan hasil rerata kadar TAG, laki-laki memiliki rata-rata kadar TAG $126,2 \mathrm{mg} / \mathrm{dL}$ dan perempuan memiliki ratarata kadar TAG $66,96 \mathrm{mg} / \mathrm{dL}$. Hal ini menunjukkan bahwa rerata kadar TAG pada laki-laki lebih tinggi daripada perempuan.

Tabel 3. Sebaran responden laki-laki menurut kadar TAG dalam darah

\begin{tabular}{|c|c|c|c|}
\hline \multirow{2}{*}{$\begin{array}{c}\text { Kadar TAG } \\
(\mathbf{m g} / \mathbf{d L})\end{array}$} & \multicolumn{3}{|c|}{ Laki-laki } \\
\hline & (n) & $(\%)$ & $\begin{array}{c}\text { Rerata TAG } \\
(\mathrm{mg} / \mathrm{dL})\end{array}$ \\
\hline $\begin{array}{l}\text { Rendah } \\
(<30)\end{array}$ & 0 & 0 & 0 \\
\hline $\begin{array}{l}\text { Normal } \\
(30-190)\end{array}$ & 21 & 84 & 109,76 \\
\hline $\begin{array}{l}\text { Tinggi } \\
(>190)\end{array}$ & 4 & 16 & 212,5 \\
\hline Total & 25 & 100 & 126,2 \\
\hline
\end{tabular}

Tabel 4. Sebaran responden perempuan menurut kadar TAG dalam darah

\begin{tabular}{cccc}
\hline \multirow{2}{*}{$\begin{array}{c}\text { Kadar TAG } \\
(\mathbf{m g} / \mathbf{d L})\end{array}$} & $(\mathrm{n})$ & $(\%)$ & $\begin{array}{c}\text { Rerata TAG } \\
(\mathrm{mg} / \mathrm{dL})\end{array}$ \\
\cline { 2 - 4 } $\begin{array}{c}\text { Rendah } \\
(<30)\end{array}$ & 0 & 0 & 0 \\
$\begin{array}{c}\text { Normal } \\
(30-190)\end{array}$ & 27 & 100 & 66,96 \\
$\begin{array}{c}\text { Tinggi } \\
(>190)\end{array}$ & 0 & 0 & 0 \\
\hline
\end{tabular}

\section{BAHASAN}

Pada penelitian ini didapatkan kadar triasilgliserol (TAG) darah pada pekerja kantor dengan aktivitas fisik rendah sebagian besar $(92,31 \%)$ memiliki kadar TAG normal. Berbeda dengan hasil penelitian LeMura dan Duvillard ${ }^{11}$ pada tahun 2004 terhadap responden dengan aktivitas fisik berat dan rendah dan ditemukan bahwa aktivitas fisik berpengaruh terhadap perubahan kadar HDL dan TAG. Kadar TAG cenderung lebih rendah terutama pada individu yang aktif. Hal ini dapat dijelaskan bahwa kadar TAG tidak hanya bergantung pada aktivitas fisik, tetapi juga oleh beberapa faktor yang lain seperti umur, jenis kelamin, konsumsi serat dan diet tinggi lemak. ${ }^{4-6}$

Peningkatan aktivitas fisik dapat dilakukan dengan berolahraga. Kadar TAG akan menurun apabila olahraga dijalankan secara teratur setidaknya $3 \mathrm{kali} /$ minggu dengan intensitas tinggi dan durasi 30 menit. ${ }^{13}$ Latihan fisik akan meningkatkan aktifitas enzim lipoprotein lipase dan hormone sensitive lipase (HSL) pada jaringan otot dan jaringan lemak, yang mengakibatkan katabolisme VLDL dan TAG meningkat, sehingga akhirnya akan meningkatkan kadar HDL dalam plasma, karena komponen hasil katabolisme VLDL merupakan salah satu pembentuk HDL. Latihan fisik juga akan menurunkan aktifitas enzim lipase dalam hati, sehingga menghambat katabolisme HDL. ${ }^{14}$

Berdasarkan penelitian yang dilakukan Sondakh $^{15}$ tahun 2012 dengan tes senam bugar pada 30 responden lansia berusia $\geq$ 60 tahun yang dilakukan selama 30 menit 
dalam 3 kali seminggu selama 3 minggu menunjukkan adanya perubahan bermakna terhadap kadar TAG dalam darah. Penelitian Liliany et al. ${ }^{16}$ tahun 2014 pada 42 responden di Puskesmas Batua Raya dan Puskesmas Bara-barayya Kota Makassar, menemukan bahwa kebiasaan olahraga dapat menurunkan kadar TAG dan LDL walaupun tidak selalu turun. ${ }^{16}$ Kadar HDL akan meningkat dan TAG akan turun jika seseorang melakukan olahraga aerobik yang dilakukan setidaknya 12 minggu berturut-turut walaupun tidak selalu berhasil. Hal tersebut tidak bertahan lama karena apabila berhenti berolahraga, kadar TAG bisa kembali ke kadar semula sebelum olahraga dimulai. Oleh karena itu, jika ingin memperbaiki dan mengontrol kadar TAG dalam darah maka perlu melakukan olahraga secara teratur. ${ }^{16}$

Kadar TAG dalam darah tidak hanya dipengaruhi oleh aktivitas fisik. Hal-hal lain yang dapat memengaruhi kadar TAG yaitu jenis kelamin, faktor usia, merokok, konsumsi alkohol, diet tinggi lemak dan konsumsi serat. ${ }^{4-6,17}$

Pada penelitian ini didapat hasil rerata kadar TAG pada laki-laki lebih tinggi dibandingkan dengan perempuan. Hasil ini sesuai dengan penelitian sebelumnya yang dilakukan oleh Fadila dan Isfarudi $^{18}$ tahun 2013 pada 153 responden di Universitas Terbuka (UT) Tangerang Selatan, yang menemukan bahwa rerata kadar TAG pada laki-laki (196,21 mg/dL) lebih besar daripada perempuan $(156,10 \mathrm{mg} / \mathrm{dL})$. Keadaan ini dapat disebabkan adanya hormon estrogen pada perempuan yang berperan dalam menjaga kadar kolesterol darah $^{19}$ dimana pada perempuan yang masih aktif menstruasi, estrogen akan menekan lipoprotein (a). ${ }^{20}$

Pada perempuan yang sudah menopause akan terjadi penurunan sintesis hormon estrogen sehingga kadar triasilgliserol darah akan meningkat. ${ }^{20}$ Sesuai dengan penelitian yang dilakukan oleh Khairani dan Sumeira ${ }^{17}$ tahun 2004 pada 307 lansia di Jakarta dengan usia $\geq 60$ tahun didapatkan hasil profil lipid menurut jenis kelamin terdapat peningkatan triasilgliserol darah pada perempuan.

Dilihat dari karakteristik responden berdasarkan usia, rerata usia pada penelitian ini yaitu 35,46 tahun dan sebagian besar responden (92,31\%) memiliki rerata kadar TAG normal yaitu $85,69 \mathrm{mg} / \mathrm{dL}$. Salah satu faktor yang mempengaruhi kadar TAG yaitu usia. Pada penelitian yang dilakukan oleh Kumesan tahun 2013 terhadap 31 responden dengan rentang usia 18-20 tahun rerata kadar TAG 64,65 mg/dL. ${ }^{21}$ Hopkins tahun 2003 dan Kwiterovich tahun 1996 dalam penelitiannya juga mengatakan bahwa pada usia yang lebih muda didapatkan kadar TAG lebih rendah dibanding usia yang lebih tua. ${ }^{22,23}$ Hasil yang sama juga ditemukan oleh Singal tahun 2012 terhadap 22 responden dengan rentang usia 40-59 tahun terdapat 3 responden $(13,63 \%)$ dengan kadar TAG yang tinggi. ${ }^{24}$

Pada penelitian ini terdapat 4 responden $(7,69 \%)$ dengan nilai TAG yang tinggi; 1 responden masih berusia 34 tahun. Penelitian yang dilakukan oleh Watuseke ${ }^{25}$ tahun 2014 pada 50 responden dengan rentang usia 15-64 tahun mendapatkan rentang usia $31-40$ tahun $(46,15 \%)$ sebagai rentang usia dengan kadar TAG tertinggi.

Pada penelitian ini terdapat 4 responden $(7,69 \%)$ dengan nilai TAG yang tinggi. Hal ini mungkin saja karena faktor konsumsi alkohol, merokok, diet tinggi lemak dan kurang konsumsi serat. ${ }^{4-6,17}$ Nikotin yang terkandung dalam rokok dapat meningkatkan lipolisis dan konsentrasi asam lemak bebas yang memengaruhi profil lipid yaitu $\mathrm{TAG}^{26}$ Penelitian yang dilakukan oleh Wowor ${ }^{26}$ tahun 2012 terhadap 56 responden pria didapatkan perbedaan kadar triasilgliserol yang bermakna pada perokok dan bukan perokok.

Pada konsumsi alkohol berlebihan terjadi peningkatkan kadar TAG sesuai dengan penelitian yang dilakukan oleh Seo et al. ${ }^{27}$ tahun 2004 pada 44 responden peminum alkohol di Korea dan usia 45 tahun. Penelitian yang dilakukan oleh Tsalissavrina et al. ${ }^{28}$ tahun 2006 kepada 21 ekor tikus wistar jantan usia 12 minggu, 
diketahui bahwa peningkatan kadar triasilgliserol terlihat lebih tinggi pada kelompok diet tinggi lemak dibandingkan diet tinggi karbohidrat. ${ }^{28}$ Penelitian oleh Reimer et al. ${ }^{29}$ tahun 2011 pada tikus putih galur sprague dawley menyebutkan bahwa konsumsi tinggi serat dapat menurunkan kadar TAG. Serat larut air berfungsi dalam memperlambat waktu pengosongan lambung, meningkatkan ketebalan lapisan intestinal yang berfungsi sebagai tempat absorpsi lipid. Selain itu, serat larut air dapat menghambat absorpsi dan metabolisme asam empedu dengan cara mengikat asam empedu dan meningkatkan pengeluarannya melalui feses. ${ }^{30}$

Keterbatasan penelitian ini antara lain tidak ada data responden tentang kebiasaan merokok, konsumsi alkohol, diet tinggi lemak, dan konsumsi serat yang merupakan faktor risiko peningkatan kadar TAG.

\section{SIMPULAN}

Berdasarkan hasil penelitian yang dilakukan dapat disimpulkan bahwa gambaran kadar triasilgliserol darah pada pekerja kantor sebagian besar dalam batas normal.

\section{SARAN}

1. Perlu menjaga kadar triasilgliserol darah dalam batas normal dengan cara rajin berolahraga, tidak merokok, tidak mengonsumsi alkohol, dan konsumsi sayur dan buah yang tinggi akan serat.

2. Perlu edukasi kepada masyarakat tentang faktor-faktor yang dapat meningkatkan kadar triasilgliserol, cara mencegah peningkatan kadar triasilgliserol dan bahaya jika memiliki kadar triasilgliserol yang tinggi.

3. Perlu dilakukan penelitian lebih lanjut dengan jumlah sampel yang lebih besar dan jenis penelitian analitik.

\section{UCAPAN TERIMA KASIH}

Ucapan terima kasih disampaikan kepada pegawai PT. Bank SULUTGO Manado, Laboratorium Klinik Patra, dan pada semua pihak yang telah menumbuhkan ide atau gagasan dalam pemikiran penulis sehingga penulis bisa menyelesaikan artikel ini.

\section{DAFTAR PUSTAKA}

1. World Health Organization. Global status report on noncommunicable diseases 2014. Geneva. Available from: http://www.who.int/nmh/publications /ncd-status-report-2014/en/. 2015. Accesed on: September $5^{\text {th }} 2016$.

2. Trihono. Laporan hasil riset kesehatan dasar (riskesdas) indonesia tahun 2013. Kementerian Kesehatan RI. Jakarta: Badan Penelitian dan Pengembangan Kesehatan Kementerian Kesehatan RI, 2013.

3. Soendoro T. Laporan hasil riset kesehatan dasar (riskesdas) indonesia tahun 2007. Kementerian Kesehatan RI. Jakarta: Badan Penelitian dan Pengembangan Kesehatan Kementerian Kesehatan RI, 2008.

4. Handajani A, Roosihermiatie B, Maryani H. Faktor-faktor yang berhubungan dengan pola kematian pada penyakit degeneratif di Indonesia. Buletin Penelitian Sistem Kesehatan 2009;13(1):42-53.

5. Sugiharto A. Faktor-faktor resiko hipertensi grade ii pada masyarakat [Tesis]. Semarang: Universitas Diponegoro.; 2007.

6. Miller M, Stone NJ, Ballantyne C, Bittner V, Criqui MH, Ginsberg HN, et al. Triglycerides and cardiovascular disease: a scientific statement from the american heart association. Circulation. 2011;123:2292-333.

7. Panil Z. Memahami Teori dan Praktik Biokimia Dasar Medis. Jakarta: EGC, 2004; p. 226-8.

8. Mann J. Penyakit kardiovaskular. In: Gibney MJ, Margarets BM, Kearner, Arab L, editors. Gizi Kesehatan Masyarakat. Jakarta: EGC, 2012; p. 391-7.

9. Nacher ELN, Colangelo L, Beam C, Greenland P. Risk factor for coronary heart disease in men 18 to 39 years of age. Ann Intern Med. 2001;134:433-9.

10. Mariduk B. Hubungan kadar adiponektin dan trigliserida serum dengan volume infark dan outcome pada pasien stroke iskemik akut [Skripsi]. Medan: 
USU Repository; 2008.

11. LeMura LM, Duvillard SPV. Clinical exercise physiology: application and physiology principles. Philadelphia: Lippincott Williams \& Wilkins, 2004; p. 70-9.

12. Kurniawati FK. Hubungan konsumsi lemak dan aktivitas fisik dengan kadar kolesterol darah dan kadar low density lipoprotein pada pasien penyakit jantung koroner rawat jalan di rumah sakit umum daerah dr. moewardi [Skripsi]. Surakarta: Universitas Muhammadiyah Surakarta; 2015.

13. Magkos F. How does exercise affect lipid metabolism? exercise for preventing hypertriglyceridemia. Available from: http://www.medscape. com/viewarticle/ 807468_1. 2013. Accesed on: September $15^{\text {th }} 2016$.

14. Sari DR. Perbedaan senam aerobik intensitas ringan dan sedang terhadap perbaikan dislipidemia pada wanita menopause.

Universitas Muhammadiyah Surakarta. Jurnal Kesehatan. 2013;6(2):187-98.

15. Sondakh R. Pengaruh senam bugar lansia terhadap kadar trigliserida. eBm. 2013;1(1):755-9.

16. Liliany EI, Jafar N, Najamuddin U. Hubungan aktivitas fisik dan pola makan terhadap komponen sindrom metabolik pada pasien rawat jalan dm tipe 2 di wilayah kerja puskesmas kota Makassar [Skripsi]. Makassar: Program Studi Ilmu Gizi Fakultas Kesehatan Masyarakat Universitas Hasanuddin; 2014.

17. Khairani R, Sumeira M. Profil lipid pada penduduk lanjut usia di Jakarta. Universa Medicina. 2005;24(4).

18. Fadila I, Isfarudi. Pengukuran kadar trigliserida darah melalui pendekatan antropometri. [Skripsi]. Universitas Terbuka Tangerang Selatan. Seminar Nasional FMIPA UNDIKSHA III. 2013.

19. Sulviana N. Analisis dan hubungan gaya hidup dan pola makan dengan kadar lipid darah dan tekanan darah pada penderita penyakit jantung koroner [Skripsi]. Bogor: Institut Pertanian Bogor; 2008.

20. Mamat, Sudikno. Faktor-faktor yang berhubungan dengan kadar hdl (analisis data of the Indonesian family life survey 2007/2008). Gizi Indon. 2010;32(2):143-9.

21. Kumesan M. Gambaran kadar triasilgliserol darah mahasiswa angkatan 2011 fakultas kedokteran universitas sam ratulangi dengan indeks massa tubuh $18,5-22,9 \mathrm{~kg} / \mathrm{m}^{2}$ [Skripsi]. Manado: Universitas Sam Ratulangi; 2013.

22. Kwiterovich PO. Lipid management in children - when and how? In: Betteridge DJ. Lipids: Current Perspectives. United Kingdom: Fournier, 1996: p. 187-202.

23. Hopkins PN, Heis G, Ellison C, Province MA, Pankow JS, Eckfeldt JH, et all. Coronary artery disease risk in familial combined hyperlipidemia and familial hypertriglyceridemia. A Case-Control Comparison From National Heart, Lung \& Blood Institute Family Heart Study. Circulation. 2003;108:519-23.

24. Singal MS. Gambaran kadar triasilgliserol darah pada laki-laki usia 40-50 tahun dengan indeks massa tubuh 18,5-22,9 $\mathrm{kg} / \mathrm{m}^{2}$ [Skripsi]. Manado: Universitas Sam Ratulangi; 2012.

25. Watuseke AE. Gambaran kadar lipid trigliserida pada pasien usia produktif di Puskesmas Bahu Kecamatan Malalayang Kota Manado periode November 2014 - Desember 2014. eBm. 2016;4(2).

26. Wowor FJ. Perbandingan kadar trigliserida darah pada pria perokok dan bukan perokok. eBm. 2013;1(2):986-90.

27. Seo JS, Yang KM, Kim JM, Min H, Kim CS, Burri BJ. Effect of chronic consumption on plasma lipid, vitamin $\mathrm{A}$, and $\mathrm{E}$ in Korean alcoholics. Nutrition Research. 2004;24:959-68.

28. Tsalissavrina I, Wahono D, Handayani D. Pengaruh pemberian diet tinggi karbohidrat dibandingkan diet tinggi lemak terhadap kadar trigliserida dan hdl darah pada rattus novergicus galur wistar. Jurnal Kedokteran Brawijaya. 2006;12(2):80-9.

29. Reimer RA, Grover GJ, Koetzner L, Gahler RJ, Lyon MR, Wood S. The soluble fiber complex polyglycoplex lowers serum triglycerides and 
reduces hepatic steatosis in highsucrose-fed rats. Faculty of Kinesiology and Department of Biochemistry \& Molecular Biology, University of Calgary, Calgary, Alberta, Canada T2N 1N4, Department of Physiology and Biophysics, Robert Wood Johnson Medical School, Piscataway, NJ 08854, USA. Nutr Res. 2011;3:296-
301.

30. Yap HC, Kui KL, Kai HY, Sheung WL. Isoflavone intake in persons at high risk of cardiovascular events: implications for vascular endothelial function and the carotid atherosclerotic burden. Am J Clin Nutr. 2007;86:938-45. 